\section{Social And Philosophical Fundamentals Of National Development}

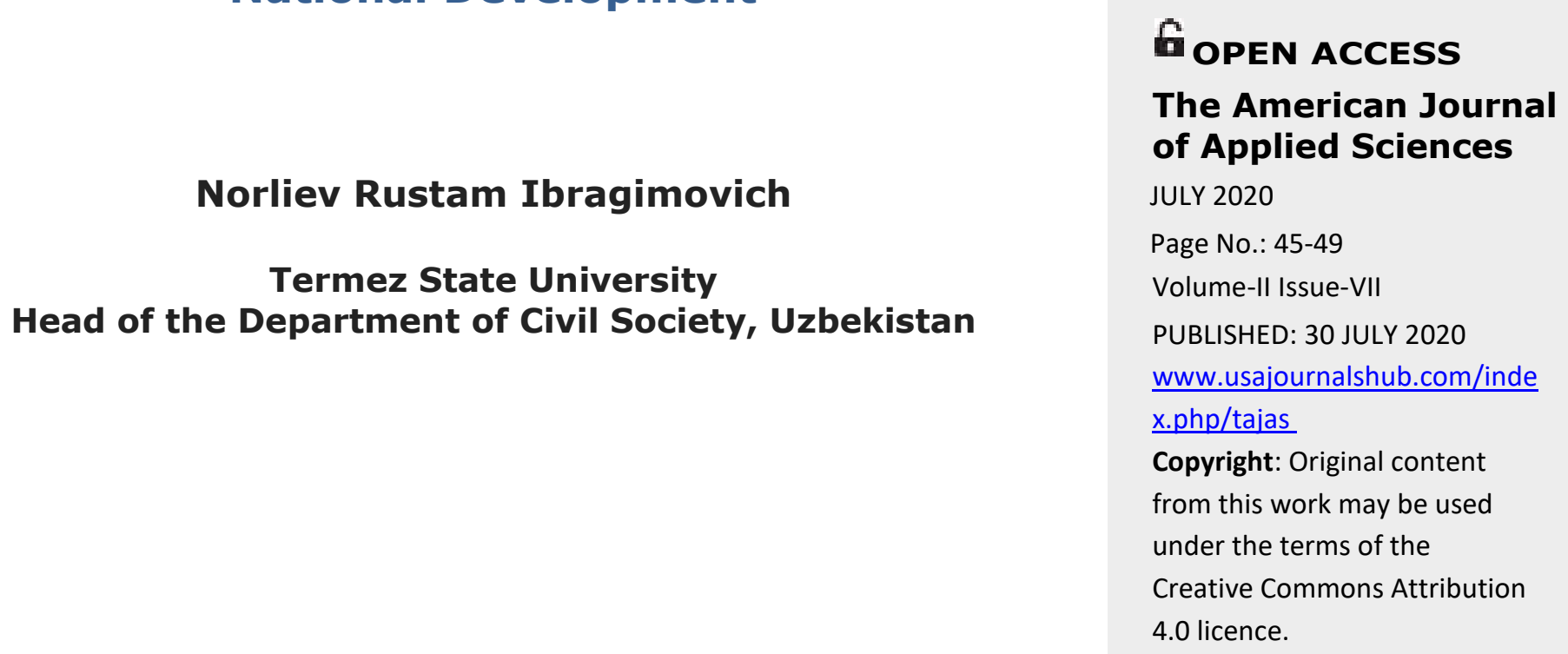

\title{
Abstract
}

This article examines the essence, characteristics, relevance and dialectical interdependence of the process of national development and spiritual growth from a sociophilosophical point of view. This philosophical study analyzes the independent approaches and views on the essence, formation, study and importance of national development and spiritual growth, based on the concept of further deepening democratic reforms and development of civil society in the country.

Keywords:National development, spiritual growth, independence, social development, democratic reforms, civil society, national idea, public organizations.

\section{Introduction}

The study of the relationship between national development and spiritual growth in the period before the independence of the Republic of Uzbekistan, in particular, the scientific analysis of its role in the development of civil society, has escaped public attention. It is safe to say that independence has brought about radical changes in the spiritual thinking and way of life of our people.The President of the Republic of Uzbekistan Shavkat 
Mirziyoyev, in his speech at the solemn ceremony dedicated to the twenty-seventh anniversary of state independence of the Republic of Uzbekistan, said: "Thanks to independence, we are equal members of the world community and build our bright future. Based on the achievements of the years of independence, we are taking a bold step from national revival to national progress. "In the current context of globalization, a philosophical analysis of the correlation between national development and the processes of spiritual growth is becoming a social necessity.In this sense, the analysis of the interrelationship of national development and spiritual progress can be justified by a number of scientific-theoretical and socio-political factors. Spiritual growth is an important criterion of national development, which allows to analyze the features of its manifestation in socio-economic, political, cultural and ideological processes, to fully understand its impact on national thinking, statehood, society and state governance. In addition, the disclosure of the internal relations of national development as a system that embodies the socio-cultural life of society and in the form of a system associated with spiritual growth is an important scientific task today theoretical, socio-practical significance. It should be noted that the ongoing social processes in society and its features related to the development of civil society in Uzbekistan are showing their universal significance. Indeed, according to the experiences of historical reality, no nation has been able to preserve its identity without spirituality. In particular, the study of its fundamental connection with the national idea, the issue of spiritual enrichment of the level of human and social development is a topical scientific problem for the ongoing democratic reforms and sociopolitical processes in our country. The issue of "spiritual growth" and "national development" is reflected in the research of many scholars. In particular, his: philosophical and moral analysis - in the works of R. Descartes, J. Locke, S. Montesquieu, D. Hume, B. Spinoza, I. Kant, I. Fixte, G. Gegel; epistemological essence of the human mind, aimed at understanding the spiritual identity - N.Berdyaev, B.Russel, V.Bexterev, I.Sechenov, S.Frank, V.Vundt, E.Durkheim, G.Lebon, V.Poreto, T.Parsons, In the studies of U. James, Z. Freud, V. Frank, E. From; Psychological and pedagogical bases A.G.Spirkin, B.G.Ananev, A.N.Leontev, V.Myasishchev, In the theoretical and experimental researches of B.D.Parigin, E.Shorokhova; social philosophical essence - A.F.Losev, M.S.Kogan, I.S.Kon, R.G.Apresyan, A.Uledov, A.Butenko, B.Grushin, V.Yadov, V.A.Lektorsky, In the works of K.N.Lyubutin, P.T.Gaydenko, L.P.Bueva, S.A.Arutyunyan, V.N.Sagatovskiy, G.S.Arefeva, L.N.Kogan, L.V.Skvortsov; The role of the individual in the system of functional relations, issues of political activity - S. Andreev, A. Belyaev, N. Ivanchuk, G. Ashin, N. Keyzerov, F. Burlatsky, A. Galkin, A. Arnoldov, V. Mejuev, A. Gurevich, Researched in the works of A. Zdravomislov, Yu.Levada. The conceptual ideas, conclusions and opinions put forward by these philosophers have influenced not only the human, individual life, existence, but also the social process of national development and spiritual uplift.M.G.Djunusov,

S.L.Rubinshteyn,

G.M.Andreeva,

B.F.Porshnev 
relations show that it is one of the most complex, comprehensive problems related to the development of society. However, the philosophical theory that dominated scientific research in the former Soviet Union did not allow the problem to be studied objectively and scientifically, and even the concepts of "national development" and "spiritual progress" were not allowed to be applied in science. However, by the end of the twentieth century, there was a growing interest in the study of national and social problems. As a result, the translation of the works of foreign researchers on the problem began to publish the results of research devoted to the study of ethnic processes, spiritual growth and the process of national development.After the independence of our country, the concepts of "spiritual growth" and "national development" began to be used as a separate sociohistorical reality, a philosophical concept that reflects the ethno-social and ethnocultural features of our people, our nation.It should be noted that the universal foundations of national development are vividly expressed in the United Nations Millennium Development Goals, the main goals of which are as follows:

leradication of extreme poverty and hunger;

laccess to general primary education;

Promoting equality between women and men and expanding women's rights and opportunities;

Ireduction of child mortality;

Improving maternal health;

Fight against HIV / AIDS, malaria and other diseases;

Ensuring environmental transparency and environmental sustainability;

I Forming a global partnership for development goals.

Each UN member state has developed its own national development direction by developing development strategies and programs to achieve the Millennium Development Goals.

defined In particular, the First President of the Republic of Uzbekistan Islam Karimov developed areas of activity that define the prospects of national development. The basis for this is the path of national development that we have chosen - the continuation of large-scale reforms in our country at a new stage; steady economic growth in Uzbekistan in the context of the global financial crisis; practical results achieved in maintaining the living standards of the population; It should be noted that the Uzbek model of development is widely recognized by the world community. It should be noted that national development is gradual. He climbed from the bottom upas a continuous process that goes on and determines the formation and rise of the nation. "National revival", which differs from national development, is a process associated with the reorientation of the potential lost at a certain stage in the history of national development due to certain objective and subjective reasons. Spiritual growth and self-awareness are the perceptions 
of each nation's place in the existential being, socio-historical and spiritual-cultural development depends on their creative activity, heuristic research, intellectual potential, and therefore the development requirements of life and activity. from the point of view of rational organization, understanding of the need for management. Unity between the nation and the representatives of the nation for the purposes of social development is the main requirement of spiritual consciousness, ascension and self-awareness. A person cannot be united with the nation without accepting its goals and ideas of social development. Independence and democratic reforms, as a great socio-political reality, have created an opportunity for our nation to realize its identity correctly and fully. Independence has made it possible to form a democratic state governed by the rule of law.Our nation, each of its representatives, has realized that he is the master, the responsible, the creator of his own life and future, that he has a place and a share in universal development. This is the rise of spirituality and the rise of self-awareness to the level of universal consciousness. The recognition of the primacy of universal values shows that the spiritual consciousness has a humanistic essence and purpose.

In conclusion, it can be said that at the current stage of development of society, the further deepening of democratic reforms in Uzbekistan, the spiritual growth of society in the context of the development of civil society, political, economic, requires the liberalization of the spiritual fronts and the continuous development of this process. Indeed, during the years of building a free, democratic society governed by the rule of law, significant work has been done on the liberalization of political and economic life, based on the legal basis. In the years of further development of independence, it is necessary to make effective use of this land and fulfill the tasks set out in the concept.

\section{REFERENCES}

1. MirziyoevSh.M. We will resolutely continue our path of national development and raise it to a new level.- T .: Uzbekistan, 2017. -592 p.

2. MirziyoyevSh.M Critical analysis, strict discipline and personal responsibility should be the daily rule of every leader. -T .: Uzbekistan 2017.

3. MirziyoevSh.M. Ensuring the rule of law and human interests is a guarantee of the country's development and the well-being of the people -T .: "Uzbekistan", 2017.

4. MirziyoevSh.M. Together we will build a free and prosperous, democratic state of Uzbekistan.-T .: Uzbekistan, 2017.

5. Azizxo'jaev A.A. National statehood and spirituality. -Tashkent: Sharq, 1997.

6. Alimardonov T. Politics and ethics. -Tashkent: Sharq, 2005.

7. Achildiev A. National idea and interethnic relations. - Tashkent: Uzbekistan, 2004. 
8. Vundt V. Problems of psychology of peoples. - SPb: Peter, 2001.

9. Galushko R.I. Zapadnoetelevideniei «massovayakultura» .- M .: MGU, 2000.

10.Jumaev R.Z. PoliticheskayasistemaRespubliki Uzbekistan: stanovlenieirazvitiya. Tashkent: Fan, 1996. 11. Mamanazarov N. National ethnic processes in Uzbekistan. Tashkent: Sharq, 2006. 12. MadaevaSh.O. National mentality and democratic thinking. Tashkent: Philosophy and Law Publishing House, 2007. 